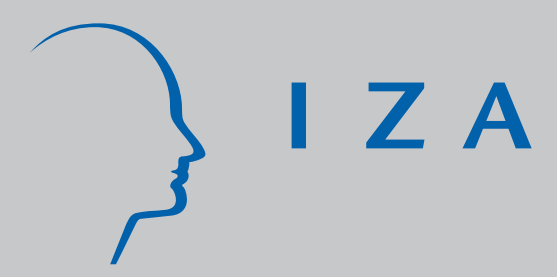

IZA DP No. 5853

Immigration, Unemployment and Growth in the Host Country: Bootstrap Panel Granger Causality Analysis on OECD Countries

Ekrame Boubtane

Dramane Coulibaly

Christophe Rault

July 2011 


\title{
Immigration, Unemployment and Growth in the Host Country: Bootstrap Panel Granger Causality Analysis on OECD Countries
}

\author{
Ekrame Boubtane \\ Paris School of Economics (University Paris 1) \\ Dramane Coulibaly \\ CEPII \\ Christophe Rault \\ LEO - University of Orléans, \\ CESifo and IZA
}

Discussion Paper No. 5853

July 2011

IZA

P.O. Box 7240

53072 Bonn

Germany

Phone: +49-228-3894-0

Fax: +49-228-3894-180

E-mail: iza@iza.org

Any opinions expressed here are those of the author(s) and not those of IZA. Research published in this series may include views on policy, but the institute itself takes no institutional policy positions.

The Institute for the Study of Labor (IZA) in Bonn is a local and virtual international research center and a place of communication between science, politics and business. IZA is an independent nonprofit organization supported by Deutsche Post Foundation. The center is associated with the University of Bonn and offers a stimulating research environment through its international network, workshops and conferences, data service, project support, research visits and doctoral program. IZA engages in (i) original and internationally competitive research in all fields of labor economics, (ii) development of policy concepts, and (iii) dissemination of research results and concepts to the interested public.

IZA Discussion Papers often represent preliminary work and are circulated to encourage discussion. Citation of such a paper should account for its provisional character. A revised version may be available directly from the author. 
IZA Discussion Paper No. 5853

July 2011

\section{ABSTRACT \\ Immigration, Unemployment and Growth in the Host Country: Bootstrap Panel Granger Causality Analysis on OECD Countries*}

This paper examines the causality relationship between immigration, unemployment and economic growth of the host country. We employ the bootstrap panel Granger causality testing approach of Kónya (2006) that allows to test for causality on each individual country separably by accounting for dependence across countries. Using annual data over the period 1980-2005 for 22 OECD countries, we find that, only in Portugal, unemployment negatively causes immigration, while in any country, immigration does not cause unemployment. We also find that, in France, Iceland, Norway and United Kingdom, growth positively causes immigration, while in any country, immigration does not cause growth.

JEL Classification: E20, F22, J61

Keywords: immigration, growth, unemployment, Granger causality

Corresponding author:

Christophe Rault

LEO

University of Orleans

Rue de Blois-B.P.6739

45067 Orléans Cedex 2

France

E-mail: christophe.rault@univ-orleans.fr

\footnotetext{
* We are grateful to the participants of the CEPII internal seminar, and of the XXV annual conference of the European Society for Population Economics for very helpful comments and suggestions on a previous version of this paper. Usual disclaimer applies.
} 


\section{Introduction}

During the last decades, most OECD countries experienced an increase in international migration. Indeed, the number of immigrants received in OECD countries substantially increased in the last decades, from about 82 million in the 1990 to 127 million in the 2010 (United Nation, 2009). Immigrants are the main source of population growth in the OECD countries. They contribute more and more to population growth, compared to natural increase (the excess of births over deaths), particularly in European countries during the last years (Figure 1). In the context of the aging population and the shrinking working age population, migration flows are likely to continue at a sustained pace in the next decades.

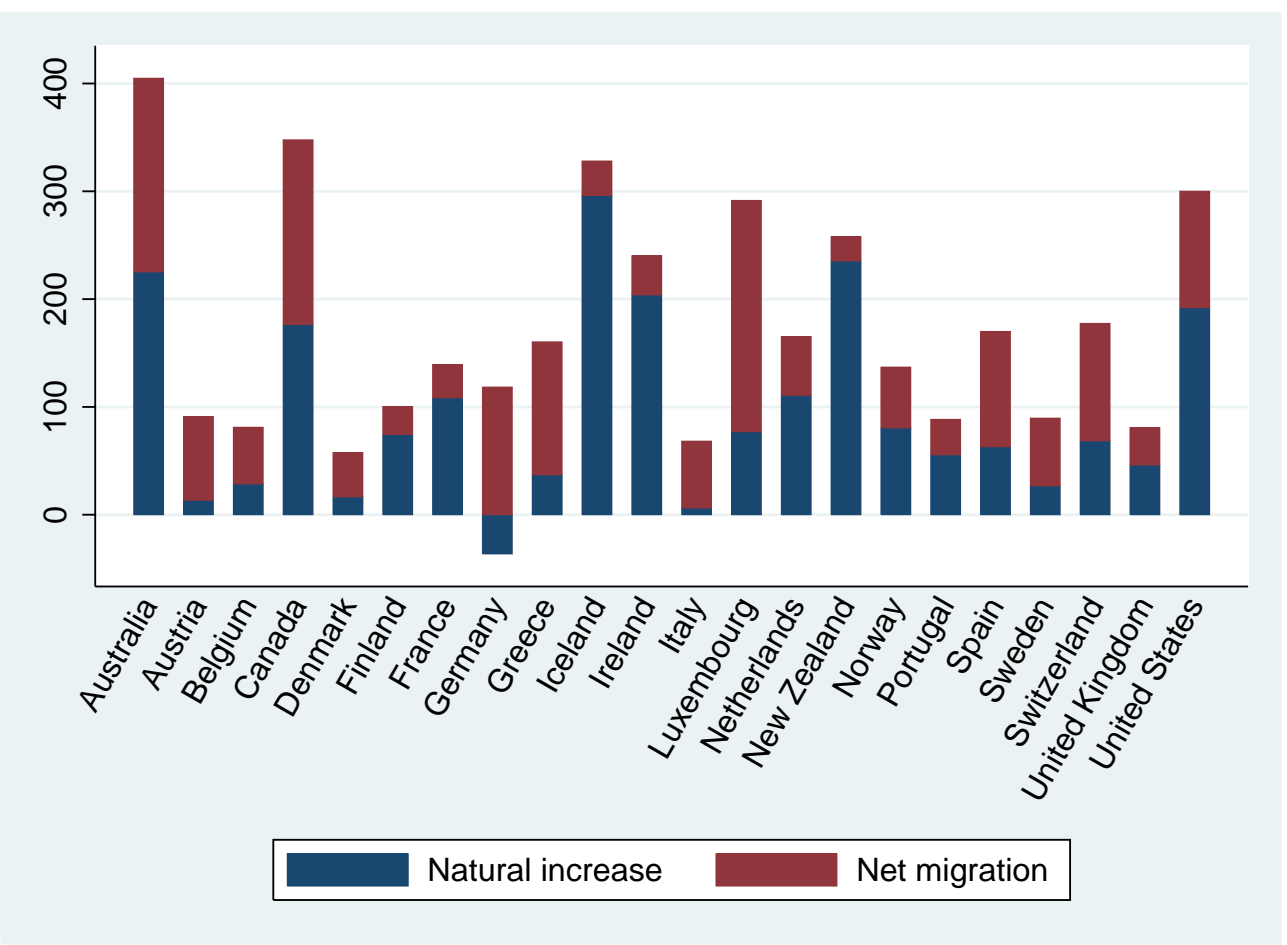

Note: Variables are in per thousand persons in the population.

Figure 1: Components of population change, 1980-2005

However, there is a public and political concern about the impact of the international migration on economic conditions in the receiving countries. Economists have studied, both theoretically and empirically, the impact of immigration on a variety of host country outcomes ${ }^{1}$ and also how economic

\footnotetext{
${ }^{1}$ See Okkerse (2008) for a review of literature.
} 
conditions in the receiving countries affect migration flows.

The theoretical studies do not draw unambiguous conclusion for the effects of immigrants on un(employment) rates among residents and natives (Harris and Todaro, 1970; Ortega, 2000). Generally, the empirical studies on the impact of immigration on labour market in host countries conclude that migration flows do not reduce the labour market prospects of natives (Simon et al., 1993; Pischke and Velling, 1997; Dustmann et al., 2005; etc.).

The theoretical studies on the effect of immigration on growth show if migrants are skill an inflow of migrants will have a less negative effect on growth than that of natural increase in population(see Dolado et al., 1994; Barro and Sala-i-Martin, 1995). This result is corroborated by the findings from the empirical papers (see Dolado et al., 1994 and Ortega and Peri, 2009 among others).

Some empirical papers have examined the causality between immigration and unemployment and growth on data from different countries (Pope and Withers, 1985 ; Marr and Siklos, 1994; Islam, 2007 and Morley, 2006). The idea is based on the fact that migrants take into account job opportunities in their decision to migrate and the economic conditions are likely to have a significant impact on migrations policies. Generally, the empirical papers on causal link between immigration and host economic activity find no evidence of migration causing unemployment and growth, but find evidence of causation running in the opposite direction.

This paper contributes to the existing literature on immigration by investigating the causality relationship between immigration and host country economic conditions (unemployment and growth) using the panel Granger causality testing approach recently developed by Kònya (2006). This approach has several advantages. Firstly, it does not assume that the panel is homogeneous and allows to test for Granger-causality on each individual panel member separately by taking into account the possible contemporaneous correlation across countries (therefore generating country specific bootstrap critical values). Therefore, it allows to test the causality relationship between immigration and host economic variables by accounting for the heterogeneity in term immigration policy of each host country. Secondly, this approach which extends the framework by Phillips (1995) that tests for noncausality in levels VARs, in a time series context, does not require pretesting for unit roots and cointegration. This is an important feature since the unit-root and cointegration tests in general suffer from low power, and different tests often lead to contradictory outcomes. Thirdly, this panel Granger causality approach allows to detect for how many and for which members of the panel there exists one-way Granger-causality, two-way Granger-causality or no Granger-causality. 
Using annual data over the period 1980-2005 for 22 OECD countries which are the major migrants-recipients countries, our study provides evidence that the interaction between immigration and host economic activity depends on the host country. Specifically, our finding suggests that, only in Portugal, unemployment negatively Granger causes immigration inflow, while in any country, immigration inflow does not Grange cause unemployment. Moreover, our results indicate that in four countries (France, Iceland, Norway and United Kingdom), economic growth positively Granger causes immigration inflow, while in any country, immigration inflow does not Granger cause economic growth.

The remainder of the paper is organized as follows. The existing literature on the interaction between immigration and unemployment and growth is reviewed in Section 2. Section 3 presents the econometric methodology. Section 4 describes the data and reports the empirical results. Finally, Section 5 offers some concluding remarks.

\section{Literature review}

Since the early 1980s a considerable literature on immigration has been developed. The main concern is about the effect of immigration on labour market and economic growth in the host country.

The theoretical studies about the effects of immigration on unemployment lead to ambiguous conclusion. Harris and Todaro (1970) use a two-sector model of migration and unemployment to describe the possible negative effects of immigration on natives employment opportunities in the presence of minimum wage. On the contrary, using a dynamic two-country labour matching model with free-entry of firms, Ortega (2000) finds a positive effect of immigration on natives employment opportunities. The theoretical papers by Johnson (1980), Borjas (1987), Schmidt et al. (1994) and Greenwood and Hunt (1995)) show that the effects of immigrants on the employment of residents depend on whether immigrants and natives are substitutes or complements in production. If the labour supply of residents and that of recent immigrants are substitutes, an inflow of immigrants will reduce the wage (assuming wage adjustment to clear the labour market) and will increase the total employment. If labour force participation rates are sensitive to real wage rates, part of adjustment will causes a decrease in natives unemployment. On the contrary, if residents and immigrant workers are complements in production (immigrants may be particularly adept at some types of jobs) the arrival of new immigrants may increase resident productivity and then raise theirs wages and theirs employment opportunities. 
Some theoretical works (Dolado et al., 1994; Barro and Sala-i-Martin, 1995) use a Solow growth model augmented by human capital to analyze the effects of immigrants on growth. They conclude that the effects of migration on economic growth depend on the skill composition of immigrants. The more migrants are educated, the more immigration has a positive effect on growth of host country.

Generally, empirical studies on the impact of immigration on labour market in host countries conclude that migration flows do not reduce the labour market prospects of natives. For example, the empirical studies based on the spatial correlation approach (Simon et al., 1993 for the U.S; Pischke and Velling, 1997 for Germany; Dustmann et al., 2005 for the U.K.) find no adverse effects of immigration on native unemployment. This result is corroborated by finding from the studies on the natural experiments, i.e., immigration caused by political rather than economic factors (Card, 1990 for the Mariel Boatlift ${ }^{2}$ and Hunt, 1992 for the repatriation of "pieds-noirs" form Algeria into France). Contrary to the studies mentioned above that are conducted at the country level, Angrist and Kugler (2003) use a panel of 18 European countries from 1983 to 1999 and find a slightly negative impact of immigrants on native labour market employment. Jean and Jimenez (2007) evaluate the unemployment impact of immigration (and its link with output and labour market policies) in 18 OECD countries over the period 1984-2003, and they do not find any permanent effect of immigration.

Estimating an augmented Solow model on data from OECD economies during the period 1960-1985, Dolado et al. (1994) find empirical evidence that corroborates its theoretical result. Their empirical result shows that because of their human capital content, migration inflows have less than half the negative impact of comparable natural population increases. However, more recently, Ortega and Peri (2009) estimate a pseudo-gravity model on 14 OECD countries over the period 1980-2005 and find that immigration does not affect income per capita.

Since migrants take into account job opportunities in their decision to migrate and because the economic conditions in host countries are likely to have a significant impact on migrations policies, some empirical papers examine whether the migration flows respond to host country economic conditions. Particularly, some previews papers examine the Granger causality links between immigration and unemployment using data on individual country (Pope and Withers, 1985 for Australia; Marr and Siklos, 1994 and Islam,

\footnotetext{
${ }^{2}$ The Martiel Boatlift occurred in 1980 when Fidel Castro permitted that Cubans who wished to leave Cuba from free access to depart from the port of Mariel. Approximately, 125000 Cubans, mostly unskilled workers, migrated to Miami. As a result, the Miami's labour force increased by 7 percent
} 
2007 for Canada). They find no evidence of migration causing higher average rates of unemployment, but find evidence of causation running in the opposite direction. However, Shan et al. (1999) find no Granger-causality between immigration and unemployment, using data from Austria and the New Zealand. Morley (2006) finds evidence of a long-run Granger causality running from per capita GDP to immigration on data for Australia, Canada and the U.S.

Contrary to these previous empirical paper that examine the Granger causality between immigration and unemployment and growth using data on individual country, we employ here panel Granger causality techniques for a panel of OECD countries.

\section{Econometric methodology}

Three approaches can implemented to test for Granger-causality in a panel framework. The first one is based on the Generalized Method of Moments (GMM) that estimates (homogeneous) panel model by eliminating the fixed effect. However, it does not account for neither heterogeneity nor the crosssectional dependence ${ }^{3}$. A second approach that deal with heterogeneity was proposed by Hurlin (2008), but its main drawback is that the possible crosssectional dependence is not taken into account. The third approach developed by Kònya (2006) allows to account for both the cross-sectional dependence and the heterogeneity. It is based on Seemingly Unrelated Regressions (SUR) systems and Wald tests with country specific bootstrap critical values and eanbles to test for Granger-causality on each individual panel member separately, by taking into account the possible contemporaneous correlation across countries. Given its generality, we will implement this last approach in this paper.

The panel causality approach by Kònya (2006) that examine the relationship between $Y$ and $X$ can be studied using the following bivariate finiteorder vector autoregressive (VAR) model:

$$
\left\{\begin{array}{l}
y_{i, t}=\alpha_{1, i}+\sum_{s=1}^{l y_{1}} \beta_{1, i, s} y_{i, t-s}+\sum_{s=1}^{l x_{1}} \gamma_{1, i, s} x_{i, t-s}+\varepsilon_{1, i, t} \\
x_{i, t}=\alpha_{2, i}+\sum_{s=1}^{l y_{2}} \beta_{2, i, s} y_{i, t-s}+\sum_{s=1}^{l x_{2}} \gamma_{2, i, s} x_{i, t-s}+\varepsilon_{2, i, t}
\end{array}\right.
$$

\footnotetext{
${ }^{3}$ Moreover, as shown by Pesaran et al. (1999) the GMM estimators can lead to inconsistent and misleading estimated parameters unless the slope coefficients are in fact identical.
} 
where the index $i(i=1, \ldots, N)$ denotes the country, the index $t(t=$ $1, \ldots, T)$ the period, $s$ the lag, and $l y_{1}, l x_{1}, l y_{2}$ and $l x_{2}$ indicate the lag lengths. The error terms, $\varepsilon_{1, i, t}$ and $\varepsilon_{2, i, t}$ are supposed to be white-noises (i.e. they have zero means, constant variances and are individually serially uncorrelated) and may be correlated with each other for a given country.

In this study, we consider two bivariate systems. In the first bivariate system System 1: $Y=U, X=M$ where $U$ and $M$ denote unemployment rate and net migration rate, respectively. In the second bivariate system System 2: $Y=L G D P, X=M$, where $L G D P$ denotes the natural logarithm of per capita real GDP (or real income).

With respect to system (1) for instance, in country $i$ there is one-way Granger-causality running from $\mathrm{X}$ to $\mathrm{Y}$ if in the first equation not all $\gamma_{1, i}$ 's are zero but in the second all $\beta_{2, i}$ 's are zero; there is one-way Granger-causality from $\mathrm{Y}$ to $\mathrm{X}$ if in the first equation all $\gamma_{1, i}$ 's are zero but in the second not all $\beta_{2, i}$ 's are zero; there is two-way Granger-causality between $\mathrm{Y}$ and $\mathrm{X}$ if neither all $\beta_{2, i}$ 's nor all $\gamma_{1, i}$ 's are zero; and there is no Granger-causality between $\mathrm{Y}$ and $\mathrm{X}$ if all $\beta_{2, i}$ 's and $\gamma_{1, i}$ 's are zero.

Since for a given country the two equations in (1) contain the same predetermined, i.e. lagged exogenous and endogenous variables, the OLS estimators of the parameters are consistent and asymptotically efficient. This suggests that the $2 \mathrm{~N}$ equations in the system can be estimated one-by-one, in any preferred order. Then, instead of $N$ VAR systems in (1), we can consider the following two sets of equations:

$$
\left\{\begin{array}{l}
y_{1, t}=\alpha_{1,1}+\sum_{s=1}^{l y_{1}} \beta_{1,1, s} y_{1, t-s}+\sum_{s=1}^{l x_{1}} \gamma_{1,1, s} x_{1, t-s}+\varepsilon_{1,1, t} \\
y_{2, t}=\alpha_{1,2}+\sum_{s=1}^{l y_{1}} \beta_{1,2, s} y_{2, t-s}+\sum_{s=1}^{l x_{1}} \gamma_{1,2, s} x_{2, t-s}+\varepsilon_{1,2, t} \\
\vdots \\
y_{N, t}=\alpha_{1, N}+\sum_{s=1}^{l y_{1}} \beta_{1, N, s} y_{N, t-s}+\sum_{s=1}^{l x_{1}} \gamma_{1, N, s} x_{N, t-s}+\varepsilon_{1, N, t}
\end{array}\right.
$$

and

$$
\left\{\begin{array}{l}
x_{1, t}=\alpha_{2,1}+\sum_{s=1}^{l y_{2}} \beta_{2,1, s} y_{1, t-s}+\sum_{s=1}^{l x_{2}} \gamma_{2,1, s} x_{1, t-s}+\varepsilon_{2,1, t} \\
x_{2, t}=\alpha_{2,2}+\sum_{s=1}^{l y_{2}} \beta_{2,2, s} y_{2, t-s}+\sum_{s=1}^{l x_{2}} \gamma_{2,2, s} x_{2, t-s}+\varepsilon_{2,2, t} \\
\vdots \\
x_{N, t}=\alpha_{2, N}+\sum_{s=1}^{l y_{2}} \beta_{2, N, s} y_{N, t-s}+\sum_{s=1}^{l x_{2}} \gamma_{2, N, s} x_{N, t-s}+\varepsilon_{2, N, t}
\end{array}\right.
$$


Compared to (1), each equation in (2), and also in (3), has different predetermined variables. The only possible link among individual regressions is contemporaneous correlation within the systems. Therefore, system 2 and 3 must be estimated by (SUR) procedure to take into account contemporaneous correlation within the systems (in presence of contemporaneous correlation the SUR estimator is more efficient than the OLS estimator). Following Kònya (2006), we use country specific bootstrap Wald critical values to implement Granger causality ${ }^{4}$.

This procedure has several advantages. Firstly, it does not assume that the panel is homogeneous, so it is possible to test for Granger-causality on each individual panel member separately. However, since contemporaneous correlation is allowed across countries, it makes possible to exploit the extra information provided by the panel data setting. Therefore, country specific bootstrap critical values are generated. Secondly, this approach does not require pretesting for unit roots and cointegration, though it still requires the specification of the lag structure. This is an important feature since the unit-root and cointegration tests in general suffer from low power, and different tests often lead to contradictory outcomes. Thirdly, this panel Granger causality approach allows the researcher to detect for how many and for which members of the panel there exists one-way Granger-causality, two-way Granger-causality or no Granger-causality.

\section{Data and Econometric investigation}

We use annual data over the period 1980-2005 for 22 OECD countries which are the major migrants-recipients countries. We use net migration, because, as mentioned by OECD, the main sources of information on migration vary across countries, which poses problems for the comparability of available data on inflows and outflows. Since the comparability problems is generally caused by short-term movements, as argued by OECD, taking net migration tends to eliminate these movements that are the main source of non-comparability. Besides, compared to data on inflows and outflows, for the countries that we consider, there are long available series on data on net migration. Net migration rate is measured as total annual arrivals less total departures, divided by the total population. Net migration data include immigrants from OECD countries and do not make a distinction between nationals and foreigners. Entries of persons admitted on a temporary basis are not included

\footnotetext{
${ }^{4}$ See Appendix for the procedure regarding how bootstrap samples are generated for each country
} 
Table 1: Descriptive statistics

\begin{tabular}{rccc}
\hline \hline Period & $\begin{array}{c}\text { Immigration } \\
\text { rate (in thousand) }\end{array}$ & $\begin{array}{c}\text { Unemployment } \\
\text { rate (in percent) }\end{array}$ & $\begin{array}{c}\text { GDP } \\
\text { per worker }\end{array}$ \\
\hline $1980-1984$ & 0.9251 & 6.81 & 18589 \\
$1985-1989$ & 1.4407 & 7.22 & 20946 \\
$1990-1994$ & 3.4877 & 8.17 & 22868 \\
$1995-1999$ & 2.8396 & 7.95 & 25460 \\
$2000-2005$ & 4.5671 & 6.05 & 29288 \\
\hline \hline
\end{tabular}

in the satistique. Only permanent and long-term mouvments are considered ${ }^{5}$. Real GDP (in 2000 Purchasing Power Parities) per capita is used to measure real income. The unemployment rate is the ratio of the labour force that actively seeks work but is unable to find work. All variables are taken from OECD Databases. Table 1 reports summary statistics of variables. The figures in Table 1 show that, on average, immigration rate increases from 0.92 per thousand during the period $1980-1984$ to 4.57 per thousand during the period 2000-2005. At the same time, GDP per capita increases, while it is difficult to point out a decrease or an increase in unemployment rate.

Since the results from the causality test may be sensitive to the lag structure, determining the optimal lag length(s) is crucial for robustness of findings. For a relatively large panel, equation- and variable-varying lag structure would lead to an increase in the computational burden substantially. To overcome this problem, following Kònya (2006) we allow maximal lags to differ across variables, but to be the same across equations. We estimate the system for each possible pair of $l y_{1}, l x_{1}, l y_{2}$, and $l x_{2}$ respectively by assuming from 1 to 4 lags and then choose the combinations minimizing the Akaike Information Criterion (AIC). The AIC selects the following lags: in the first bivariate system $l y_{1}=2, l x_{1}=1, l y_{2}=1$, and $l x_{2}=1$; and in the second bivariate system $l y_{1}=2, l x_{1}=1, l y_{2}=1$ and $l x_{2}=2$.

As mentioned above, testing for the cross-sectional dependence in a panel causality study is crucial for selecting the appropriate estimator. Following Kònya (2006) and Kar et al. (2010), to investigate the existence of crosssectional dependence we employ three different tests: Lagrange multiplier test statistic for cross-sectional dependence of Breusch and Pagan (1980), and two cross-sectional dependence tests statistic of Pesaran (2004), one based on Lagrange multiplier and the other based on the pair-wise correlation coefficients.

\footnotetext{
${ }^{5}$ Unauthorised migrants are not taken into account at the time of arrival. They may be included when they are regularised and obtain a long-term status in the country.
} 
Table 2: Results for cross-sectional dependence tests

\begin{tabular}{|c|c|c|c|}
\hline \multirow[b]{2}{*}{ Model } & \multicolumn{3}{|c|}{ Test Statistic } \\
\hline & $C D_{B P}$ & $C D_{L M}$ & $C D$ \\
\hline System 1 (U) & $\begin{array}{c}450.7726^{* * *} \\
(0.000)\end{array}$ & $\begin{array}{c}10.2246^{* * *} \\
(0.000)\end{array}$ & $\begin{array}{c}83.1740^{* * *} \\
(0.000)\end{array}$ \\
\hline System 1 (M) & $\begin{array}{l}280.7111^{*} \\
(0.0141)\end{array}$ & $\begin{array}{c}2.3128 \\
(0.0207)\end{array}$ & $\begin{array}{c}35.8008^{* * *} \\
(0.000)\end{array}$ \\
\hline System 2 (LGDP) & $\begin{array}{c}709.8659 * * * \\
(0.000)\end{array}$ & $\begin{array}{c}22.2789^{* * *} \\
(0.000)\end{array}$ & $\begin{array}{c}131.8569 * * * \\
(0.000)\end{array}$ \\
\hline System 2 (M) & $\begin{array}{c}308.4733^{* *} \\
(0.0005)\end{array}$ & $\begin{array}{l}3.6044^{* * *} \\
(0.0003)\end{array}$ & $\begin{array}{c}12.2688^{* * *} \\
(0.000)\end{array}$ \\
\hline
\end{tabular}

$C D_{B P}, C D_{L M}$ and $C D$ denotes the test statistic of Breusch and Pagan Lagrange multiplier statistic for cross-sectional dependence, Pesaran Lagrange multiplier statistic for cross-sectional dependence and Pesaran cross-sectional dependence statistic based on the pair-wise correlation coefficients, respectively. Under the null hypothesis of no cross-sectional dependence, $C D_{B P}$ follows a chi-square distribution with $N(N-1) / 2$ degrees of freedom, $C D_{L M}$ and $C D$ follow standard normal distribution . ${ }^{* * *}, * *$ and $*$ indicate rejection of the null hypothesis at 1 and 5 and 10 percent level of significance, respectively.

The Lagrange multiplier test statistic for cross-sectional dependence of Breusch and Pagan (1980) is given by:

$$
C D_{B P}=T \sum_{i=1}^{N-1} \sum_{j=i+1}^{N} \hat{\rho}_{i j}^{2}
$$

where $\hat{\rho}_{i j}$ is the estimated correlation coefficient among the residuals obtained from individual OLS estimations. Under the null hypothesis of no cross-sectional dependence with a fixed $\mathrm{N}$ and large $\mathrm{T}, C D_{B P}$ asymptotically follows a chi-squared distribution with $N(N-1) / 2$ degrees of freedom (Greene (2003), p.350).

Since, BP test has a drawback when N is large Pesaran (2004) proposes another Lagrange multiplier $\left(C D_{L M}\right)$ statistic for cross-sectional dependence that does nor suffer from this problem. The $C D_{L M}$ statistic is given as follows: 


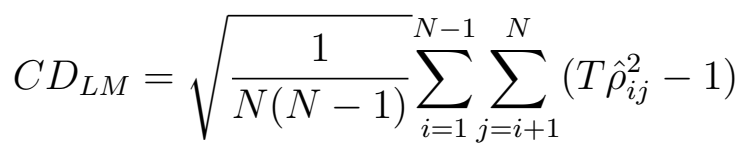

Under the null hypothesis of no cross-sectional dependence with the first $T \rightarrow$ $\infty$ and then $N \rightarrow \infty, C D_{L M}$ asymptotically follows a normal distribution. However, this test is likely to exhibit substantial size distortions when $\mathrm{N}$ is large relative to T. Pesaran (2004) proposes a new test for cross-sectional dependence $(C D)$ that can be used where $\mathrm{N}$ is large and $\mathrm{T}$ is small. This test is based on the pair-wise correlation coefficients rather than their squares used in the LM test. The $C D$ statistic is given by:

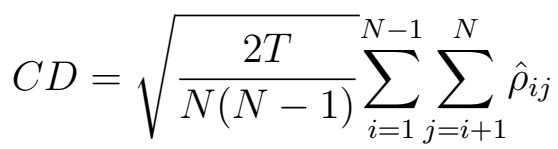

Under the null hypothesis of no cross-sectional dependence with the $T \rightarrow$ $\infty$ and then $N \rightarrow \infty$ in any order, $C D$ asymptotically follows a normal distribution. Pesaran (2004) show that the $C D$ test is likely to have good small sample properties (for both $\mathrm{N}$ and $\mathrm{T}$ small).

Table 2 reports the results of these cross-sectional dependence tests. The results in 2 show that all the three tests reject the null of no cross-sectional dependence across the members of the panel at $5 \%$ level of significance, implying that the SUR method is appropriate rather than a country-by-country OLS estimation. The cross-sectional dependence tests confirm that a strong economic links exist between OECD countries members.

\section{$5 \quad$ Results and Discussions}

Table 3-6 report the results of Granger causality. Notice that the bootstrap critical values are substantially higher than the chi-square critical values usually applied with the Wald test, and that they vary considerably from a country to another and across tables ${ }^{6}$. The results of causality tests from immigration to unemployment and from unemployment to immigration are displayed in Table 3 and Table 4, respectively. The results of causality form immigration to GDP and from GDP to immigration are displayed in Table 5 and Table 6 , respectively. In the tables $3-6$, the column 'estimated coefficient' represents the estimated coefficient of $x_{t-1}\left(y_{t-1}\right)$ in the equation testing from Granger causality from $X$ to $Y(Y$ to $X)$.

\footnotetext{
${ }^{6}$ The chi-square critical values for one degree of freedom, i.e. for Wald tests with one restriction, are $6.6349,3.8415,2.7055$ for $1 \%, 5 \%$ and $10 \%$, respectively.
} 
Table 3: Granger causality tests immigration to unemployment

\begin{tabular}{lrrrrr}
\hline \hline Country & Estimated & Test Stat. & \multicolumn{3}{c}{ Bootstrap critical values } \\
& coefficient & & $1 \%$ & \multicolumn{1}{c}{$5 \%$} & \multicolumn{1}{c}{$10 \%$} \\
\hline Australia & 0.1938 & 13.0198 & 287.7363 & 138.7766 & 90.6493 \\
Austria & 0.0234 & 5.6799 & 286.6355 & 125.8565 & 80.5467 \\
Belgium & -0.1245 & 3.6805 & 175.4215 & 77.6084 & 50.1208 \\
Canada & 0.0059 & 0.0140 & 274.5667 & 139.4946 & 91.9954 \\
Denmark & -0.2288 & 5.7721 & 337.5072 & 140.8359 & 90.8154 \\
Finland & 1.2062 & 52.9716 & 316.3091 & 150.2173 & 96.7384 \\
France & -0.0292 & 0.0222 & 173.9483 & 81.8138 & 52.8704 \\
Germany & 0.0173 & 1.9601 & 295.8401 & 139.7354 & 93.7130 \\
Greece & 0.0821 & 9.0246 & 230.2833 & 109.3694 & 72.4079 \\
Iceland & 0.0610 & 15.7417 & 286.9114 & 132.6577 & 86.1520 \\
Ireland & -0.1138 & 23.1385 & 342.9583 & 154.8923 & 103.2070 \\
Italy & -0.0583 & 11.3306 & 207.7941 & 85.4204 & 54.6998 \\
Luxembourg & 0.0072 & 2.4710 & 331.8680 & 159.0345 & 106.0899 \\
Netherlands & 0.1967 & 11.7020 & 230.3935 & 99.0387 & 62.2805 \\
New Zealand & -0.0130 & 0.4398 & 248.4385 & 112.1155 & 75.7471 \\
Norway & 0.2627 & 58.7593 & 303.4181 & 134.9851 & 85.3963 \\
Portugal & 0.0218 & 0.6693 & 156.7490 & 75.7666 & 49.2947 \\
Spain & -0.2794 & 57.3525 & 241.2615 & 110.0584 & 72.6988 \\
Sweden & 0.0373 & 1.2791 & 404.1338 & 196.2905 & 125.7544 \\
Switzerland & 0.0767 & 35.3416 & 296.1276 & 143.5848 & 92.3061 \\
United Kingdom & -0.1357 & 3.8144 & 263.5924 & 119.9834 & 77.9560 \\
United States & -0.1908 & 7.7114 & 284.1708 & 132.2164 & 83.6499 \\
\hline \hline
\end{tabular}

Note: $H_{0}$ : immigration does not cause unemployment. The column "Estimated coefficient" denotes the estimated coefficient of lag of immigration rate in the equation testing Granger causality from immigration to unemployment rate. ***, **, and * indicate rejection of the null hypothesis at the 1,5 , and 10 percent levels of significance, respectively. 
Table 4: Granger causality tests unemployment to immigration

\begin{tabular}{|c|c|c|c|c|c|}
\hline \multirow{2}{*}{ Country } & \multirow{2}{*}{$\begin{array}{c}\text { Estimated } \\
\text { coefficient }\end{array}$} & \multirow[t]{2}{*}{ Test Stat. } & \multicolumn{3}{|c|}{ Bootstrap critical values } \\
\hline & & & $1 \%$ & $5 \%$ & $10 \%$ \\
\hline Australia & -0.3315 & 8.2290 & 306.8964 & 143.4189 & 93.5239 \\
\hline Austria & 0.0892 & 0.0347 & 326.9468 & 141.4868 & 90.3277 \\
\hline Belgium & -0.0858 & 13.4350 & 206.6685 & 90.3308 & 58.6337 \\
\hline Canada & -0.2170 & 6.5177 & 292.1500 & 125.6811 & 80.9669 \\
\hline Denmark & 0.1012 & 4.8414 & 350.6973 & 150.9016 & 100.5670 \\
\hline Finland & -0.0378 & 9.5450 & 273.6004 & 130.8957 & 85.1077 \\
\hline France & -0.0540 & 16.1243 & 290.4957 & 147.3383 & 99.4058 \\
\hline Germany & -0.0490 & 0.1187 & 294.3776 & 144.2217 & 95.1106 \\
\hline Greece & -0.0161 & 0.0375 & 341.1858 & 171.5095 & 111.4617 \\
\hline Iceland & -0.2756 & 1.1717 & 218.2504 & 100.4272 & 64.8144 \\
\hline Ireland & -0.3785 & 5.1142 & 244.2332 & 107.9090 & 69.3826 \\
\hline Italy & -0.1845 & 1.7309 & 369.5746 & 169.3226 & 113.8005 \\
\hline Luxembourg & 1.4298 & 5.7080 & 207.6518 & 99.2973 & 64.7285 \\
\hline Netherlands & 0.1746 & 16.5221 & 236.9243 & 124.0193 & 81.6781 \\
\hline New Zealand & 0.2662 & 1.7910 & 290.4320 & 134.6834 & 85.8611 \\
\hline Norway & 0.0597 & 0.3610 & 264.9229 & 119.5181 & 74.3819 \\
\hline Portugal & -0.6033 & $122.3191^{*}$ & 334.0911 & 146.9617 & 97.5169 \\
\hline Spain & -0.1282 & 6.1913 & 132.1068 & 59.5167 & 38.1426 \\
\hline Sweden & -0.0153 & 0.1089 & 232.5700 & 108.9333 & 69.3073 \\
\hline Switzerland & -0.5030 & 14.4276 & 241.6980 & 116.7093 & 76.3445 \\
\hline United Kingdom & -0.0364 & 0.6224 & 221.8538 & 102.3553 & 66.4853 \\
\hline United States & -0.0649 & 4.0023 & 314.9698 & 153.4151 & 100.2002 \\
\hline
\end{tabular}


Table 5: Granger causality tests immigration to GDP

\begin{tabular}{lrrrrr}
\hline \hline Country & Estimated & Test Stat. & \multicolumn{3}{c}{ Bootstrap critical values } \\
& coefficient & & $1 \%$ & $5 \%$ & $10 \%$ \\
\hline Australia & -0.0062 & 145.2363 & 642.1363 & 300.2588 & 184.0594 \\
Austria & -0.0014 & 20.1850 & 509.7105 & 216.5362 & 133.1134 \\
Belgium & -0.0030 & 18.2444 & 681.2106 & 284.3846 & 186.9683 \\
Canada & -0.0071 & 107.2464 & 908.8519 & 393.7506 & 258.2969 \\
Denmark & -0.0000 & 0.0018 & 651.5292 & 255.4873 & 155.2668 \\
Finland & -0.0223 & 136.2913 & 603.1720 & 268.2465 & 169.2409 \\
France & -0.0207 & 103.0732 & 585.3197 & 304.6188 & 206.4012 \\
Germany & 0.0004 & 7.8763 & 558.5621 & 269.2568 & 182.6525 \\
Greece & -0.0007 & 0.6512 & 185.0076 & 83.9402 & 53.1138 \\
Iceland & -0.0041 & 25.0658 & 528.0840 & 232.1546 & 141.7218 \\
Ireland & -0.0016 & 23.6291 & 531.9374 & 223.8201 & 144.6197 \\
Italy & -0.0004 & 1.1934 & 524.0714 & 244.2464 & 159.6062 \\
Luxembourg & 0.0001 & 0.0160 & 475.9581 & 197.6779 & 119.3652 \\
Netherlands & -0.0028 & 24.4681 & 609.2427 & 270.3311 & 176.1551 \\
New Zealand & -0.0005 & 1.9322 & 528.0105 & 229.6578 & 144.5666 \\
Norway & -0.0036 & 38.4940 & 883.3209 & 343.9916 & 215.0718 \\
Portugal & -0.0010 & 1.0132 & 472.0737 & 216.6576 & 137.7028 \\
Spain & -0.0000 & 0.0004 & 517.1960 & 249.8073 & 168.2989 \\
Sweden & -0.0021 & 7.7808 & 704.4112 & 310.1129 & 197.6469 \\
Switzerland & -0.0026 & 28.3606 & 491.3078 & 230.0392 & 150.7396 \\
United Kingdom & -0.0039 & 24.8869 & 770.9085 & 344.2256 & 229.1871 \\
United States & -0.0016 & 1.4538 & 638.4730 & 305.0717 & 199.0662 \\
\hline \hline
\end{tabular}

Note: $H_{0}$ : immigration does not cause GDP. The column "Estimated coefficient" denotes the coefficient of the lag of the immigration rate in the equation testing for Granger causality from immigration rate to LOG(GDP). ${ }^{* *},{ }^{* *}$, and * indicate rejection of the null hypothesis at the 1,5 , and 10 percent levels of significance, respectively. 
Table 6: Granger causality tests GDP to immigration

\begin{tabular}{lrrrrc}
\hline \hline Country & Estimated & Test Stat. & \multicolumn{3}{c}{ Bootstrap critical values } \\
& coefficient & & \multicolumn{1}{c}{$1 \%$} & \multicolumn{1}{c}{$5 \%$} & $10 \%$ \\
\hline Australia & 0.5966 & 0.2133 & 44.1132 & 21.2758 & 14.2802 \\
Austria & 4.1763 & 3.0485 & 69.4796 & 31.4398 & 19.9934 \\
Belgium & 2.2344 & 7.9633 & 165.3051 & 81.3064 & 53.7078 \\
Canada & 4.7688 & 16.5011 & 67.4497 & 31.3532 & 20.3437 \\
Denmark & 0.9893 & 0.5960 & 64.1267 & 29.2654 & 19.2426 \\
Finland & 0.7857 & 4.5312 & 96.3905 & 45.0952 & 28.9216 \\
France & 0.3803 & $14.5200^{*}$ & 38.4159 & 19.2248 & 12.9537 \\
Germany & -1.9891 & 0.5180 & 103.0069 & 50.1292 & 32.2102 \\
Greece & -1.6919 & 1.8655 & 190.9693 & 90.9634 & 60.1493 \\
Iceland & 19.4588 & $72.6350^{* *}$ & 78.6381 & 34.7857 & 21.7824 \\
Ireland & 12.0384 & 37.9026 & 229.9758 & 104.5681 & 68.5805 \\
Italy & 5.5991 & 7.6469 & 42.8646 & 21.7309 & 14.0878 \\
Luxembourg & 2.1905 & 1.8097 & 77.9690 & 36.2650 & 22.8619 \\
Netherlands & -1.3450 & 2.8127 & 57.4609 & 25.3127 & 16.4470 \\
New Zealand & 14.6758 & 8.0079 & 70.7573 & 32.1478 & 20.4502 \\
Norway & 4.9385 & $43.0513^{* * *}$ & 42.8830 & 21.1842 & 13.4986 \\
Portugal & 3.2272 & 19.6184 & 175.9970 & 80.2091 & 51.6689 \\
Spain & 4.7815 & 13.5030 & 243.5550 & 128.0488 & 89.6999 \\
Sweden & 1.4345 & 0.9856 & 66.7698 & 29.7692 & 19.2975 \\
Switzerland & 3.9219 & 1.3726 & 93.4584 & 43.4481 & 27.4950 \\
United Kingdom & 3.9982 & $34.5706^{* *}$ & 66.1783 & 29.5176 & 18.6249 \\
United States & 0.3443 & 0.4280 & 93.8299 & 42.5891 & 27.7797 \\
\hline \hline
\end{tabular}

Note: $H_{0}$ : GDP does not cause immigration. The column "Estimated coefficient" denotes the coefficient of the lag of the immigration rate in the equation testing for Granger causality from LOG(GDP) to immigration rate. ${ }^{* * *}, * *$, and $*$ indicate rejection of the null hypothesis at the 1,5 , and 10 percent levels of significance, respectively. 
The results in Table 3 show that, in any country, there is no causality from immigration to unemployment. Table 4 shows that, for only Portugal, there is a significant (at the $10 \%$ level of significance) negative causality running from unemployment to immigration, while for the other countries there is no significant causality running from unemployment to immigration.

The results in Table 5 suggest that, in any country, there is no significant causality running from immigration to GDP. Table 6 shows that in four countries (France, Iceland, Norway and United Kingdom) there is a positive significant causality running from GDP to immigration; while in the other countries there is no significant causality running from GDP to immigration. There is a positive causality running from GDP to immigration at 1 percent level of significance for Norway, 5 percent level of significance for Iceland and United Kingdom Norway and 10 percent level of significance for France.

Our study shows evidence that the interaction between immigration and host economic activity depends on the host country that we consider. Our findings suggest that, only in Portugal, immigration inflow negatively responds to unemployment, while in any country, unemployment does not respond to immigration inflow. Our results also find that, in four countries (France, Iceland, Norway and United Kingdom), immigration inflow positively responds to economic growth, while in any country, economic growth does not respond to immigration inflow.

The fact that immigration does not impact host economic variables can be explained by the evidence that the human capital content of migration inflow is high in order to compensate the negative effects of immigration on output (Dolado et al., 1994). As a result there will be no negative impact of immigration on growth and employment. The findings from this paper support the results from some previews studies (Simon et al., 1993; Dolado et al., 1994; Marr and Siklos, 1994; Pischke and Velling, 1997; Dustmann et al., 2005 Ortega and Peri (2009)).

The findings of causality from immigration to host economic variables can be related to the characteristics of countries immigration policies. For example, the negative influence of unemployment on immigration in Portugal can be explained as follow. Portugal, a country with long history of expatiation, has become significant immigration country recently. Foremost, immigration flows to Portugal were mainly from its former colonies (Brazil and Portuguese-Speaking African Countries (PALOP)). Since the 1990s, a large proportion of "new" immigrants with economic reason come from Europe and Asia. The needs of Portuguese employers play a significant role in the recruitment process of the newly arrived immigrants. Accordingly, the Portuguese government adjusts its migration policy according to the requirement of the labour market. Finally, immigrants, both Portuguese nationals 
and foreign, are more likely to immigrate to a third European country when the labour market situation is less favorable.

For the four countries (France, Iceland, Norway and United Kingdom), the explanations of positive impact of growth on immigration are as follow. The positive influence of the economic growth on migration flows may be related to the family reunification requirements. In France, family component is the main channel of entry for long-term immigrants. In order to bring their families, immigrants have to satisfy a minimum level of income. During a period of higher growth, immigrants have great possibility to satisfy this minimum level of income criteria. Moreover, economic migration to France mainly includes immigrants from European countries (such as Portugal) that are attracted by better economic prospects.

Norway and Iceland are two small countries with high incomes and high demand for labour. So, the main attraction for immigrants to these two countries is the high standard of living. A large percentage of labour immigration is from Nordic neighbors and OECD countries. The booming economy and the increased demand of labour in Norway and Island led authorities to admit economic immigrants during the last years.

Finally, the explanation of the result for the United-Kingdom can be explained by the fact that the immigrants to the United Kingdom are more attracted by the prospect of higher wages produced by the greater economic growth. In the United Kingdom, labour migration represents a sizable percentage of total inflows (44 percent in 2005$)^{7}$. If family members accompanying workers are taken into account, the percentage of economic migration is around 60 percent in 2005 . The inflow of labour migration increased from 124 thousands on average per year in the 1980s to 200 thousands in the 1990s. From 2000 to 2005, the labour migration inflows reached 333 thousand per year on average.

\section{Concluding Remarks}

This paper examines the causality between immigration and the economic conditions of host countries (unemployment and growth). We employ the panel Granger causality testing approach recently developed by Kònya (2006) that is based on SUR systems and Wald tests with country specific bootstrap critical values. We use annual data over the period 1980-2005 for 22 OECD countries which are the major migrants-recipients countries.

\footnotetext{
${ }^{7}$ The work category combines two IPS reasons for migration: "definite job" and "looking for work". Authors' calculation is based on Office for National Statistics (2008, 2009).
} 
Our study provides evidence that the interaction between immigration and host economic activity depends on the host country. On the one hand, our finding suggests that, only in Portugal, unemployment negatively Granger causes immigration inflow, while in any country, immigration inflow does not Grange cause unemployment. On the other hand, our results find that, in four countries (France, Iceland, Norway and United Kingdom), economic growth positively Granger causes immigration inflow, while in any country, immigration inflow does not Granger cause economic growth.

Our results confirm that the levels of immigration tend to be highly regulated (or migrants are selected contingent on theirs skills). Because of high skill of migrants, the human capital content of a migration inflow is high in order to compensate the negative effects of immigration on economic growth (Dolado et al., 1994). As a result there will be no negative effect of immigration on host economic growth and employment.

In order to tackle the problem of aging population, many OECD countries see immigration as a potential solution to compensate for the labour shortage. Our results indicate that immigration flows do not harm the employment prospects of residents. Hence, OECD countries may receive more migrants, without fearing about a potential negative impact on growth and employment. 


\section{Appendix: The bootstrap procedure}

The procedure to generate bootstrap samples and country specific critical values (in the test of no causality from $X$ to $Y$ ) consists of the following five steps (Kònya, 2006)

1st step: Implement an estimation of (2) under the null hypothesis of nocausality from $\mathrm{X}$ to $\mathrm{Y}$ by (i.e. imposing $\gamma_{1, i, s}=0$ the for all $i$ and $s$ ) and get the corresponding residuals:

$$
e_{H_{0}, i, t}=y_{i, t}-\hat{\alpha}_{i, 1}+\sum_{s=1}^{l y_{1}} \hat{\beta}_{1, i, s} y_{i, t-s}
$$

From these residuals, build the $N \times T\left[e_{H_{0}, i, t}\right]$ matrix.

2nd step: In order to preserve the contemporaneous dependence between error terms in (2), randomly select a full column from $\left[e_{H_{0}, i, t}\right]$ matrix at a time (i.e do not draw the residuals for each country one-by-one); and denote the selected bootstrap residuals as $\left[e_{H_{0}, i, t}^{*}\right]$ where $t=1, \ldots, T^{*}$ and $T^{*}$ can be greater than $\mathrm{T}$.

3rd step: Build the bootstrap sample of $\mathrm{Y}$ under the hypothesis of nocausality from $\mathrm{X}$ to $\mathrm{Y}$, i.e. using the following formula:

$$
y_{i, t}^{*}=\hat{\alpha}_{i, 1}+\sum_{s=1}^{l y_{1}} \hat{\beta}_{1, i, s} y_{i, t-s}^{*}+e_{H_{0}, i, t}^{*}
$$

4th step: Replace $y_{i, t}$ by $y_{i, t}^{*}$, estimate (2) without any parameter restrictions and then implement the Wald test for each country to test for the no-causality null hypothesis.

5th step: Develop the empirical distributions of the Wald test statistics by repeating (10,000 replications) the steps $2-4$ many times and build the bootstrap critical values. 


\section{References}

Angrist, J.D. and A.D. Kugler. 2003. "Protective or counter-productive? Labour market institutions and the effect of immigration on EU natives?" Economic Journal, 113, 302-331.

Barro, R. and X. Sala-i-Martin. 1995. Economic Growth. McGraw-Hill. New York

Breusch, T. and A. Pagan. 1980. "The LM test and its applications to model specification in econometrics," Review of Economic Studies, 47, 239-254.

Borjas, G. 1987. "Immigrants, minorities, and labor market competition," Industrial and Labor Relations Review, 40, 382-392.

Card, D. 1990. "The impact of the Mariel boatlift on the Miami labor market," Industrial and Labor Relations Review, 43, 245-257.

Card, D. 2001. "Immigrant inflows, native outflows and the local labor market impacts of higher immigration," Journal of Labor Economics, 19, 22-64.

Dolado, J., A. Goria and A. Ichino. 1994. "Immigration, human capital and growth in the host country: evidence from pooled country Data," Journal of Population Economics, 7, 193-215.

Dustmann, C., F. Fabbri and I. Preston. 2005. "The Impact of Immigration on the British Labour Market," The Economic Journal, 115, 324-341.

Greene, W.H., (2003). Econometric Analysis. 2nd ed. Prentice-Hall.

Greenwood, M.J and G.L Hunt. 1995. "Economic effects of immigrants on native and foreign-born workers: Complementarity, substitutability, and other channels of influence," Southern Economic Journal, 61, 1076-1097.

Grossman, J.B. 1982. "The Substitutability of Natives and Immigrants in Production," Review of Economics and Statistics, 64, 596-603.

Harris, J. and M. Todaro. 1970. "Migration, Unemployment and Development: A Two-sector Analysis," American Economic Review, 60, 126-142.

Hunt, J. 1992. "The impact of the 1962 repatriates from Algeria on the French labor market," Industrial and Labor Relations Review, 45, 556-572.

Hurlin, C. 2008. "Testing for Granger Non Causality in Heterogeneous Panels," Mimeo, Department of Economics, University of Orleans.

Im, K., H. Pesaran and Y. Shin. 2003. "Testing for Unit Roots in Heterogeneous Panels," Journal of Econometrics, 115, 53-74.

Islam, A. (2007). "Immigration and Unemployment Relationship: Evidence from Canada," Australian Economic Papers, 46, 52-66.

Jean, S. and M. Jimenez. 2007. "The Unemployment Impact of Immigration in OECD Countries," OECD Economics Department Working Paper, No. 
563.

Johnson, G.E. 1980. "The labor market effects of immigration," Industrial and Labor Relations Review, 33, 331-341.

Kar, M., S. Nazloğluc and H. A $\breve{g r}$. 2010. "Financial development and economic growth nexus in the MENA countries: Bootstrap panel granger causality analysis," Economic Modelling, 28, 685-693.

Kònya, L. 2006. "Exports and growth: Granger causality analysis on OECD Countries with a panel data approach," Economic Modelling, 23, 978-992.

Marr, W. and P. Siklos. 1994. "The Link between Immigration and Unemployment in Canada," Journal of Policy Modeling, 16, 1-26.

Morley, B. 2006. "Causality between economic growth and immigration: An ARDL bounds testing approach," Economics Letters, 90, 72-76.

Office for National Statistics 2008. Long-term international migration estimates from the International Passenger Survey (IPS): 1975-1990.

2009. Long-term international migration from International Passenger Survey (IPS) tables: 1991-latest.

Okkerse, L. 2008. "How to measure labour market effects of immigration: A review," Journal of Economic Surveys, 22, 1-30.

Ortega, J. 2000. "Pareto Improving Immigration in an Economy with Equilibrium Unemployment," The Economic Journal, 110, 92-112.

Ortega, F. and G. Peri. 2009. "The Causes and Effects of International Migrations: Evidence from OECD Countries 1980-2005," NBER Working Paper No. 14833.

Pesaran, M.H. 2004. "General Diagnostic Tests for Cross Section Dependence in Panels," CESifo Working Paper 1229; IZA Discussion Paper 1240.

Pesaran, M.H., Y. Shin and R.J. Smith. 1999. "Pooled Mean Group Estimation of Dynamic Heterogeneous Panels," Journal of the American Statistical Association, 94, 621-634.

Pischke, J. and J. Velling. 1997. "Employment effects of immigration to Germany: an analysis based on local labor markets," Review of Economics and Statistics, 79, 594-604.

Phillips, P.C.B. 1995. "Fully modified least squares and vector autoregression. Econometrica, 63, 1023-1078.

Pope, D. and Withers, G. 1985. "Immigration and Unemployment," Economic Record, 61, 554-563.

Schmidt, M., A. Stilz and K. Zimmermann, 1994. "Mass migration, unions, and government intervention," Journal of Public Economics, 55, 185-201. 
Shan, J, A. Morris and F. Sun. 1999. "Immigration and Unemployment: New evidence from Australia and New Zealand," International Review of Applied Economics, 13, 253-258.

Simon, J.L., S. Moore and R. Sullivan. 1993. "The effect of immigration on aggregate native unemployment: an across-city estimation," Journal of Labor Research, 14, 299-316.

Zellner, A. 1962. "An efficient method of estimating seemingly unrelated regressions and tests for aggregation bias," Journal of the American Statistical Association, 57, 348-368. 